NBER WORKING PAPER SERIES

\title{
SOCIOECONOMIC DIFFERENCES IN THE HEALTH OF BLACK UNION ARMY SOLDIERS
}

\author{
Chulhee Lee \\ Working Paper 14745 \\ http://www.nber.org/papers/w14745 \\ NATIONAL BUREAU OF ECONOMIC RESEARCH \\ 1050 Massachusetts Avenue \\ Cambridge, MA 02138 \\ February 2009
}

I would like to thank Robert Fogel and Stanley Engerman for the helpful discussions and advice, the participants in the 2006 NBER Cohort Studies Meeting and two anonymous referees for their useful comments and suggestions, and Nathaniel Grotte for editorial assistance. This research is supported by National Institute on Aging, the National Institute of Health (PO1AG10120). Remaining errors are my own. The views expressed herein are those of the author(s) and do not necessarily reflect the views of the National Bureau of Economic Research.

NBER working papers are circulated for discussion and comment purposes. They have not been peerreviewed or been subject to the review by the NBER Board of Directors that accompanies official NBER publications.

(C) 2009 by Chulhee Lee. All rights reserved. Short sections of text, not to exceed two paragraphs, may be quoted without explicit permission provided that full credit, including $\odot$ notice, is given to the source. 
Socioeconomic Differences in the Health of Black Union Army Soldiers

Chulhee Lee

NBER Working Paper No. 14745

February 2009

JEL No. N31,N41

\begin{abstract}
This paper investigates patterns of socioeconomic difference in the wartime morbidity and mortality of black Union Army soldiers. Among the factors that contributed to a lower probability of contracting and dying from diseases were (1) lighter skin color, (2) a non-field occupation, (3) residence on a large plantation, and (4) residence in a rural area prior to enlistment. Patterns of disease-specific mortality and timing of death suggest that the differences in the development of immunity against diseases and in nutritional status prior to enlistment were responsible for the observed socioeconomic differences in wartime health. For example, the advantages of light-skinned soldiers over dark-skinned and of enlisted men formerly engaged in non-field occupations over field hands resulted from differences in nutritional status. The lower wartime mortality of ex-slaves from large plantations can be explained by their better-developed immunity as well as superior nutritional status. The results of this paper suggest that there were substantial disparities in the health of the slave population on the eve of the Civil War.
\end{abstract}

\author{
Chulhee Lee \\ Department of Economics \\ Seoul National University \\ Kwanak-ro 599, Kwanak-gu \\ Seoul 151-742, S. KOREA \\ chullee@snu.ac.kr
}




\section{Introduction}

The major purpose of this article is to explore the socioeconomic differences in the health and mortality of ex-slave Union Army soldiers. More specifically, it investigates how the probabilities of suffering from illnesses and dying from diseases were related to the socioeconomic backgrounds of black servicemen prior to the war. Special attention is given to the relationship between prior exposure to disease and the later health of ex-slaves. As will be discussed below, this study is related to some broader issues pertaining to the patterns of health disparities and the role of disease environment in shaping the lives of the slave population in the antebellum South. ${ }^{2}$

In studies of U.S. mortality differentials prior to the twentieth century, blacks have often been compared as a single group to whites or the population at large. The racial differences in mortality and health are now fairly well established. Available data have suggested that the mortality of blacks was considerably higher than that of whites in the mid-nineteenth century. The life expectancies at birth circa 1850 for whites and blacks were 39.5 years and 23 years; the numbers of deaths per 1000 infants were 216 and 340, respectively (Haines 2000, 158).

More detailed studies of the slave population based on plantation records have suggested that the racial differences in the measures of health were primarily due to the early-life malnutrition of slaves. The age profile of height shows that the size of slaves below age five was exceedingly small because of nutritional deficiencies (Steckel 1986). The excess death rates of children below age five accounted for nearly all of the racial differences in mortality; the mortality of slaves after age 10 was similar to that of whites. The stunted final height of slaves can also be explained by early malnutrition. Slaves were shorter because of the nutritional deficiencies of early childhood but heavier in terms of

\footnotetext{
2 The disparity in measures of health among slaves remains one of the less explored aspects of U.S. slavery, mainly due to the lack of vital data prior to the twentieth century. An official Death Registration Area consisting of ten states and the District of Columbia was established in 1900, and data collection from all states was not complete until 1933. Even in the early twentieth century, the black population was underrepresented in the Death Registration Areas. The currently available mortality statistics for the nineteenth century are based mostly on less systematic sources (Haines 2000, 145-151).
} 
weight per inch of height. This indicates that late adolescent and adult slaves were probably better nourished than whites (Fogel 1989, chapter 5, Fogel, Galantine, and Manning 1992, \#47).

Although blacks in the mid nineteenth century-and especially slaves in the antebellum South - were perhaps a more homogeneous population than whites in terms of socioeconomic status, it appears that there was considerable variation among slaves in terms of economic well-being and ecological environment according to their occupation, skin color, and plantation size. Existing evidence suggests that mortality rates on rice plantations exceeded those on cotton plantations. Disparate environmental conditions (such as the effect of population aggregation on the rate of spread of diseases) and the intensity of work according to the type of crop may have played a major role (Fogel 1989, 127).

Occupational differences in mortality among slaves have also been found. Male artisans were less than half as likely to die during a given year as male field hands at the same age. The excess mortality among field hands was perhaps produced by the greater intensity of work and inadequate sanitary conditions for those who worked with animal manure during the planting season. This "sanitary condition hypothesis" is supported by the fact that dysentery and tetanus, which are promoted by poor sanitation and hygiene, were two of the leading causes of death (Fogel 1989, 128). Margo and Steckel (1992) found that light-skinned ex-slaves were taller than dark-skinned persons. They also found height disadvantages associated with living on large plantations and residing in urban areas.

This paper is distinct from existing studies on socioeconomic differences in the health of the U.S. slave population in several respects. This is the first attempt to examine how and why the wartime diseases and deaths of the Union Army troops differed by personal characteristics and prior place of residence. An advantage of looking into the wartime experiences is that detailed descriptions of disease diagnoses and the cause and date of death while in service are contained in the Union Army medical records. These rich sources make it possible to examine the patterns of diseases, cause-specific mortality, and timing of deaths as well as general mortality, which have not been done by previous studies.

Secondly, the special conditions of an army camp during the war provide a unique 
chance to determine the relationship between socioeconomic background and health. The Civil War brought together a large number of ex-slaves with heterogeneous personal characteristics and ecological backgrounds into an extremely unhealthy environment that caused unusually high rates of disease contraction and consequent mortality. Upon being mustered into the service, ex-slaves were confined to relatively homogeneous living conditions in terms of quality of diet, housing, and disease environment. Owing to these features of army life, it is possible to more clearly identify the effects of socioeconomic and ecological factors on the degree of susceptibility or resistance to disease.

\section{Military Service Records of Black Union Army Soldiers}

Shortly after the outbreak of the American Civil War, leaders of black communities and prominent white abolitionists in the North demanded that black people be allowed to join the Union Army, expecting that fighting in the war would pave a way toward liberation for slaves and greater rights for free black people. ${ }^{3}$ As the Northern soldiers advanced to Southern states, many slaves escaped to the territories occupied by the Union Army, providing the Union with a potential pool of military manpower. In the early stages of the war, however, Union policy makers were highly reluctant to recruit black men in spite of potential military advantages on the grounds that the capability of black men to fight in battles was doubtful, and because enlisting black men into the Union Army could support the claims of black people to the full citizenship that most Northerners refused to concede.

Some high-ranking officers, who felt very strongly about the need to organize black units among fugitive slaves and freemen, moved ahead to recruit, organize, and train black regiments. In doing so of their own volition, these generals faced official censure and possible dismissal from the service in disgrace and well as disapproval from military peers. ${ }^{4}$ Only during 1863 were black men enlisted into Union ranks on a large scale. Repeated

\footnotetext{
${ }^{3}$ See Berlin, Reidy, and Rowland $(1982,1998)$ and Hargrove (1988) for the history of the Colored Troops in the Union Army.

${ }^{4}$ The early black regiments that were organized by such pioneers include the South Carolina Regiment (organized by Major General David Hunter), the Kansas Regiment (organized by General James Henry Land), and the Louisiana Native Guard Regiments (organized by Major-General Benjamin Butler and Brigadier-General John Phelps).
} 
defeats of Union Army regiments and growing difficulties in recruiting white volunteers were major forces responsible for the turnaround of the Union recruitment policy. After the Emancipation Proclamation on January 1, 1863, Northern states started to recruit and organize "colored regiments." The Bureau for Colored Troops was established on May 22, 1863, finally creating a coordinated policy for recruitment, organization, administration, and services for all black regiments, which included white officers. During the Civil War, 179,000 black men enlisted in the Union Army, of whom 146,000 were from slave states, including the border states (Delaware, Maryland, Missouri, and Kentucky).

The present study is based on a sample of 5677 black Union Army soldiers in 51 infantry companies who were linked to their military service records. ${ }^{5}$ The service records contain very detailed descriptions of the diseases or wounds that recruits suffered during military service. As soon as a recruit was too ill to report for duty, his condition was noted in morning reports. If his condition required medical attention, it was recorded in the regimental surgeon's report; if he was hospitalized, the diagnosis of the disease was described in the case history together with the ultimate outcome, such as return to service, discharge for disabilities, or death (U.S. Surgeon General's Office 1870, vol. 1). Information on disease and on date and cause of death in service was gathered from these sources. Military service records also provide information on demographic and socioeconomic characteristics of recruits, such as age, occupation at enlistment, place of birth, and height, among other variables, as well as information about military careers, including rank, military duty, company, regiment, change in military status, dates of enlistment and discharge, and so on.

\footnotetext{
${ }^{5}$ This sample has been collected and linked as part of the project titled "Early Indicators of Later Work Levels, Disease, and Death," jointly sponsored by the National Bureau of Economic Research, the National Institutes of Health, the Center for Population Economics at the University of Chicago, and Brigham Young University. See Fogel (1993, 2000a, 2000b, 2001) and Wimmer (2003) for more detailed explanations of the EI Project and data produced from the project. The data sets collected and linked as part of this project can be obtained from the Center for Population Economics Web site (http://www.cpe.uchicago.edu).
} 
Table 1

Medical Experiences in Service and Personal Characteristics of Black Union Army Recruits:

A Comparison of Three Samples

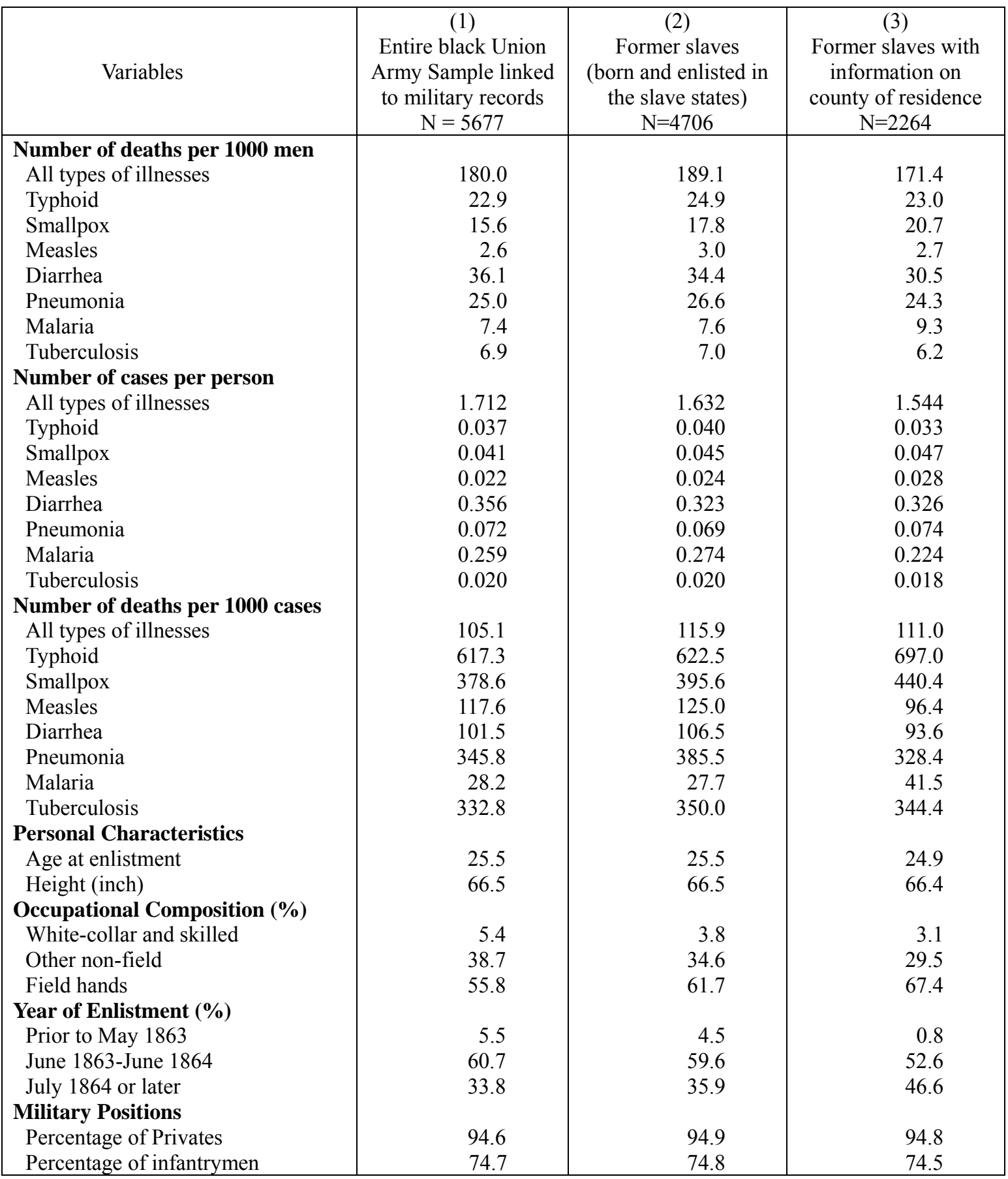

Notes: The county of residence refers to either the county of birth enlistment (for those who provided that information) or the county of enlistment (the rest of the recruits). See text for the definition of the variables. 
I selected ex-slaves from this sample based on the states of birth and enlistment. For many black recruits, the place of enlistment may not have been the place of residence prior to service. Because of the changes in the principles of recruitment of blacks in the Union Army, many moved to other states to join the Union Army before recruitment was permitted in their home state. For instance, many blacks in Kentucky had fled to enlist in Northern and Tennessee regiments (Berlin, Reidy, and Rowland 1998). Likewise, a large number of blacks in slave states, for whom enlistment was a road to freedom, moved to Northern states where they could join the Union Army. To make sure that only former slaves are included, I limited the sample to the 4706 men who were born and enlisted in slave states.

Previous studies based on samples of white Union Army recruits suggest that the degree of exposure to disease prior to enlistment was an important determinant of the probabilities of contracting disease and death while in service (Lee 1997, 2003). To consider the effect of county-specific ecological environments, I further selected a sample of 2264 black soldiers for whom either the county of birth or the county of enlistment are known.

Table 1 compares the medical experiences while in service and selected personal characteristics of the black recruits who belonged to these three samples. The entire sample and the sample of ex-slaves are matched fairly well in wartime mortality from disease, number of cases per person, and case-fatality rate of wartime diseases. The two samples are also similar in other personal characteristics and military experiences except for the occupational composition. The percentages of whitecollar/skilled and other non-farm occupations are somewhat higher for the full sample than for the sample of ex-slaves. The samples of all ex-slaves and those with information on county (cols. 2 and 3 ) are also generally similar in wartime medical experiences and other personal characteristics, although the percentages of non-farm occupations are lower for the latter. Also, men who enlisted prior to the establishment of the Bureau for Colored Troops in May 1863 are underrepresented in the sample of ex-slaves with information on county. This might indicate that military service records were less complete for those who joined the army before systematic recruitment of blacks started.

The analyses given below rely on a sample of ex-slaves who joined the Union 
Army and a subsample of these men for whom the information on the county of residence prior to enlistment is available. Even if we cannot preclude the possibility of sample selection bias, Table 1 suggests that the magnitude of the bias should not be large. Thus, the results of this study are likely to represent the experiences of the Union Army Colored Troops.

A remaining question is whether the sample of soldiers represents the entire slave population at military service age. Because no random sample of slaves circa 1860 is currently available, it is difficult to offer a decisive answer to this question. However, the following pieces of circumstantial evidence suggest that the sample used in this paper may not be too different from the entire male slave population at military service ages during the Civil War. First, previous studies have indicated that while warrelated biases were present, the relationships among civilian occupation and personal characteristics of ex-slaves in the Union Army were similar to those present in the civilian slave population (Margo 1992). Second, white Union Army soldiers were similar to the entire white male population in the North in terms of wealth and other personal characteristics (Fogel 1993). Third, about 35 percent of the Northern white males of military service age served in the armed forces during the war; the proportion of military-age black males who served in the Union Army was even higher. Finally, in examining the physical fitness of volunteers, it appears that lower standards were applied to ex-slaves than to whites (Berlin, Reidy, and Rowland 1982, chapter 15). For these reasons, the colored troops may represent the entire male slave population at military age, at least as much as white Union Army soldiers' experiences convey those for all Northern white males.

\section{Socioeconomic Background, Disease, and Mortality}

Wartime casualty by disease was much higher for black recruits than for white soldiers. Eighteen percent of black servicemen in the sample examined in this study were killed by disease whereas 8 percent of white men in the entire Union Army died from illness while in service. The wartime casualty rates of the sample are well matched to the entire black regiments of 179,000 men, of which 33,000 soldiers (18.4 percent) were killed by disease while in service. Disease was by far the predominant cause of wartime mortality for black men, accounting for ten out of every eleven 
deaths. The ratio of the number of deaths from disease to wound-caused deaths was much higher for blacks than white soldiers. The seven most common diseases in army camps were typhoid, smallpox, measles, diarrhea (including dysentery), pneumonia, malaria, and tuberculosis. These diseases were responsible for about two thirds of all deaths caused by illness and half of all disease cases. Of these diseases, diarrhea was the single greatest killer, accounting for 20 percent of all deaths caused by disease, followed by pneumonia (14 percent) and typhoid (13 percent).

The unusually high rate of mortality from disease among black soldiers raised considerable concerns among commanding officers of black regiments and medical staffs of the Union Army. Some attributed the high wartime death rate of blacks to the fact that many black recruits came ill prepared for soldiering in the first place. According to this claim, slavery left black men weak and susceptible to disease, and the Union recruitment placed many men under arms who would otherwise have been disqualified. Others blamed the poor living conditions that black recruits confronted in the army camps, including deficiency of qualified medical personnel, stationing at particularly unhealthy posts, disproportionately greater fatigue duty, unbalanced diets, and indifferent treatment from white commanders (Berlin, Reidy, and Rowland 1982, chapter 15).

In the balance of this paper, I focus on how the wartime mortality of black soldiers differed by socioeconomic characteristics, leaving aside the question of why blacks were much more likely to be killed by disease than whites. I first calculated the wartime mortality from disease in general, the mean number of cases per person, and the case fatality rates of all diseases for black recruits according to their age, skin color, height, occupation, average farm size of county, population density of county, and region of residence. The mean number of cases of disease per person-year reflects how susceptible recruits of a particular characteristic were to disease, while the case fatality rates indicate how robust they were in resisting the diseases they contracted. The disease-caused mortality in general is determined by these two indexes. ${ }^{6}$

\footnotetext{
${ }^{6}$ In addition, the probabilities of contracting and dying from diseases for a particular demographic group were determined by their average length of service. Unfortunately, the average length of service can be calculated for less than 30 percent of the sample because the information on dates of enlistment or discharge is missing for many soldiers. It is implicitly assumed in Table 2 that the length of military service is the same for each cell composed of
} 
Previous studies have suggested that slaves were treated differently according to their skin color. Planters in Trinidad, for instance, had a strong bias in favor of assigning light-skinned creoles to elite occupations. Light-skinned males were more than twice as likely to be artisans or hold another non-field job as dark-skinned males. A light-skinned woman was over six times as likely to be chosen as a domestic as a dark-skinned woman. Studies of the New Orleans slave records also show the effect of color on selection for elite jobs, although the effect was much weaker in the United States than in Trinidad (Fogel 1989, 48-50). Although the evidence regarding the effect of skin color has been centered on occupational assignment, light-skinned slaves could also have been treated favorably in other ways if planters had a preference for lighter skin color. ${ }^{7}$ Skin colors were classified into three categories, (1) dark, (2) brown, and (3) light.

It is widely accepted that adult height is an index of cumulative net nutritional status over the growing ages and a powerful predictor of health at older age (Fogel 1994, Waaler 1984). Because it is inappropriate to compare the height of a recruit at a growing age with the height of one who had already gained his final stature, it is desirable to use an age-standardized measure of height. Accordingly, five dummy variables on height (Height 1 to Height 5) have been constructed, each of which represents a quintile of the height distribution for a particular age. The height distribution by age was obtained from the entire black Union Army sample of 5677. To all recruits 23 and older, a single height distribution was applied, assuming that height after age 23 remained unchanged.

Occupation is one of the most widely used indicators of socioeconomic status in the nineteenth century United States. The occupations of ex-slaves were classified to the following three categories based on the typical job hierarchy of slaves: (1) elite occupations such as managers and craftsmen, (2) other non-field occupations and domestics, and (3) field hands. In the antebellum South, it was a common practice that

particular socioeconomic characteristics.

${ }^{7}$ It appears that slave holders of the British Caribbean and planters in Charleston, New Orleans, and some other cities had a relatively strong preference for light-skinned slaves to work in the house. If the American South as a whole is examined, however, it is less clear what role skin color played in determining a master's attitude towards slaves. According to Genovese (1976), whites did not show any great partiality to mulattoes, except when they were blood relatives. 
more productive and loyal slaves were promoted to elite occupations. Occupational promotions were used as a reward for hard work and an incentive to elicit greater effort from field workers. In determining a slave's occupation, planters tried to match the slave's human capital and a job's requirements as closely as possible (Fogel 1989, Chapter 2).

Domestic servants and slaves assigned to elite occupations should have enjoyed better diets and housing compared to the majority engaged in field work. Eugene Genovese described the privileges given to drivers as follows: "The privileges accruing to drivers varied a great deal but usually included some extra food and clothing, as well as allotments of tobacco and whiskey. Sometimes they lived in more comfortable quarters than the others. The most valued could expect cash bonuses of five or ten dollars at Christmas time.... [T] hey escaped the most boring, brutal, and demoralizing features of the gang-labor system (Genovese 1976, 370)." Similarly, "house servants fared much better than field hands: they had more and better food and clothing, more comfortable quarters, and more personal consideration from the whites (Genovese 1976, 331)." In addition, the black recruits who had held elite occupations presumably had superior health compared with field hands owing to the selective nature of occupational assignment and the privileges associated with their occupations. $^{8}$

The prior exposure to disease was an important determinant of wartime disease and mortality for white Union Army soldiers (Lee 1997, 2003). Farmers and rural residents, who were healthier on average prior to enlistment owing to a greater extent of isolation from other people, were more likely to succumb to illness and to be killed by disease than non-farmers and urban dwellers, respectively. The different degree of immunity to pathogens is probably the most important link between the extent of prior exposure to disease and later health. That is, despite the negative consequences for net nutritional status, survivors of unhealthy environments developed better immunity to some of the infectious diseases that were rampant in army life.

\footnotetext{
${ }^{8}$ Slave artisans and drivers (overseers of gang-system) were indeed taller than field hands (Fogel 1989).
} 
Table 2

Wartime Morbidity and Mortality from All Types of Diseases by Personal Characteristics

\begin{tabular}{|c|c|c|c|c|}
\hline & $\begin{array}{c}(1) \\
\text { Number }\end{array}$ & $\begin{array}{c}(2) \\
\text { Deaths per } \\
1000 \text { Men }\end{array}$ & $\begin{array}{c}(3) \\
\text { Cases per } \\
\text { Person }\end{array}$ & $\begin{array}{c}\text { (4) } \\
\text { Deaths per } \\
1000 \text { Cases }\end{array}$ \\
\hline \multicolumn{5}{|l|}{ Skin color } \\
\hline Black & 3321 & 176.8 & 1.520 & 116.3 \\
\hline Brown & 278 & 100.7 & 0.799 & 126.0 \\
\hline Light & 166 & 108.4 & 1.259 & 86.1 \\
\hline \multicolumn{5}{|l|}{ Height } \\
\hline Shortest Quintile & 792 & 160.3 & 1.196 & 134.0 \\
\hline Second Quintile & 839 & 158.5 & 1.409 & 112.5 \\
\hline Third Quintile & 704 & 179.0 & 1.723 & 103.9 \\
\hline Fourth Quintile & 928 & 178.9 & 1.605 & 111.5 \\
\hline Tallest Quintile & 673 & 167.9 & 1.489 & 112.8 \\
\hline \multicolumn{5}{|l|}{ Occupation } \\
\hline Skilled & 159 & 138.4 & 1.723 & 80.3 \\
\hline Non-farm & 1419 & 139.5 & 1.190 & 117.2 \\
\hline Field hand & 2469 & 185.5 & 1.623 & 114.3 \\
\hline \multicolumn{5}{|l|}{ Farm size } \\
\hline Lowest Quintile & 294 & 193.9 & 1.432 & 136.3 \\
\hline Second Quintile & 413 & 181.6 & 1.419 & 128.0 \\
\hline Third Quintile & 491 & 181.3 & 1.621 & 111.8 \\
\hline Fourth Quintile & 350 & 148.6 & 1.283 & 115.8 \\
\hline Highest Quintile & 511 & 99.8 & 1.102 & 90.6 \\
\hline \multicolumn{5}{|l|}{ Pop density } \\
\hline Lowest Quintile & 392 & 120.0 & 0.946 & 126.8 \\
\hline Second Quintile & 412 & 138.3 & 1.148 & 120.5 \\
\hline Third Quintile & 483 & 202.9 & 1.557 & 130.3 \\
\hline Fourth Quintile & 439 & 173.1 & 1.747 & 99.1 \\
\hline Highest Quintile & 334 & 137.7 & 1.353 & 101.8 \\
\hline \multicolumn{5}{|l|}{ Region } \\
\hline Confederacy & 2450 & 182.4 & 1.283 & 142.2 \\
\hline Union Slave States & 1679 & 149.5 & 1.745 & 85.7 \\
\hline
\end{tabular}

Source: Sample of black Union Army soldiers.

To consider the effect of the disease environment of the community, two different measures of population aggregation were employed: the plantation size and the population density. These variables were constructed by dividing the sample into five categories of equal size according to the average number of slaves per slave holder and the population density of the county where the recruits had lived prior to enlistment. Recruits from larger plantations and men from more densely populated counties should have had more contact with disease than, respectively, enlistees from smaller plantations and those from more isolated areas. In addition to the extent of exposure to disease, plantation size may capture the quality and quantity of food offered to slaves. The differences between former slaves from Union slave states and from Southern Confederate states were also considered. This regional division is 
expected to capture the health effects of the differences in climate and ecological environment between the two regions.

The results of the computations are reported in Table 2. Black soldiers with lighter skin colors (either brown or light) were much less likely to die from disease than those with darker skin colors. The lower disease-caused death rates for brownskinned men are entirely attributable to the lower probability of contracting disease compared to dark-skinned men. On the other hand, the advantages of light-skinned solders over men with darker skin colors are explained by both their lower rates of contraction and case fatality. The effect of height does not stand out clearly.

The men who were formerly engaged in elite occupations were much less likely to die from disease than field hands because their chances of surviving diseases in case of contraction were higher. The mortality from disease for other non-farm occupations was as low as the death rate for elite occupations, but their advantages over field hands resulted exclusively from their lower probability of contracting diseases.

Ex-slaves from larger plantations appear to have been much less likely to be killed by disease while in service than men from smaller plantations. In particular, men who had resided in the counties belonging to the top quintile in terms of the average plantation size were half as likely to die from disease as those from the counties in the bottom quintile. The advantages of having resided in a large plantation prior to enlistment were due to both the lower probability of contracting diseases and the lower conditional probability of dying from diseases contracted.

No clear relationship was observed between population density and degree of susceptibility to disease, measured by the number of cases per person. On the other hand, recruits from more densely populated counties (counties that belonged to the top 40 percent of the distribution of the county population density) were more robust in resisting diseases that they contracted, as indicated by the relatively low case fatality rate.

Lastly, the wartime disease mortality was lower for black men from the border states than those from Confederate states, but not by much. The higher rate of contraction for men enlisted into the border state regiments was more than offset by their lower case fatality rate. The measures of wartime health computed separately for 
four different age categories (ages 17-19, 20-24, 25-29, and 30 or older), not reported in this paper, suggest that the patterns of mortality differentials for all ages described above are generally true for each of the four age groups.

Logistic regressions were performed to examine the effect of each of the socioeconomic characteristics, controlling for all other factors at the same time. Three different models were employed. The first and second regressions estimated the effect of each independent variable on the probabilities of contracting a disease and dying from a disease (respectively) while in service, based on the entire sample of black soldiers with information on county of residence. In the third regression, the sample was limited to the recruits who experienced at least one illness while in service. ${ }^{9}$ The second regression examines the determinants of the degree of susceptibility to disease, whereas the third is concerned with fatality in case of contraction. The result of the first regression on mortality shows the combined consequence of the differences in susceptibility and lethality.

In addition to the variables on age, skin color, height, occupation, plantation size, population density, and region of residence (definitions are explained above), variables pertaining to the year of enlistment and military positions are added. The timing of enlistment could have influenced wartime disease and the mortality of black recruits. There were two fundamental changes in the War Department's approach to the recruitment of blacks that should have altered the treatment of black men in the army. Prior to the spring of 1863 , as noted above, black soldiers were recruited on an ad hoc basis by individual Union commanders as Union political leaders hesitated to allow the enlistment of black men. In May 1863, the War Department finally started full-scale enlistment, establishing the Bureau of Colored Troops to regulate and supervise the enlistment of black soldiers and the selection of officers to command black regiments.

\footnotetext{
${ }^{9}$ A soldier who had been killed in action would no longer be able to contract a disease. Also, an early discharge from service would diminish the length of time at risk for having an illness. These competing risks could not be properly treated by the logistic models employed in this study. This problem is at least partially addressed by the hazard analysis offered in the next section. Exclusion of the soldiers who died from wounds did not change the results much, perhaps because their number was too small and deaths from wounds were relatively random events.
} 
Table 3

Results of Logistic Regressions: Correlates of Probability of Dying from Disease $\left(\partial P / \partial x_{\mathrm{i}}\right)$

\begin{tabular}{|c|c|c|c|c|c|}
\hline \multirow[b]{2}{*}{ Independent Variables } & \multicolumn{3}{|c|}{ All Recruits } & \multicolumn{2}{|c|}{$\begin{array}{c}\text { Recruits Who Contracted } \\
\text { Disease }\end{array}$} \\
\hline & Mean & $\begin{array}{c}(1) \\
\text { Dying from } \\
\text { Disease } \\
(\text { mean }= \\
0.157)\end{array}$ & $\begin{array}{c}(2) \\
\text { Contracting } \\
\text { Disease } \\
(\text { mean }= \\
0.518)\end{array}$ & Mean & $\begin{array}{c}(3) \\
\text { Dying from } \\
\text { Disease } \\
(\text { mean }= \\
0.291)\end{array}$ \\
\hline Age & 25.231 & -0.033 & $-0.054+$ & 25.263 & -0.019 \\
\hline $\operatorname{Age}^{2} \times 10^{-1}$ & 70.555 & 0.009 & $0.008+$ & 71.063 & 0.007 \\
\hline Skin color brown & 0.077 & $-0.528 * *$ & $-0.579 * * *$ & 0.036 & -0.174 \\
\hline Skin color light & 0.045 & 0.048 & -0.286 & 0.043 & 0.140 \\
\hline Height 1 (shortest $\left.5^{\text {th }}\right)$ & 0.210 & $-0.353 * *$ & $-0.255 *$ & 0.200 & $-0.317+$ \\
\hline Height 2 & 0.200 & $-0.362 * *$ & $-0.259 *$ & 0.185 & $-0.341 *$ \\
\hline Height 4 & 0.256 & $-0.273+$ & 0.049 & 0.166 & $-0.350 *$ \\
\hline Height 5 (tallest $\left.5^{\text {th }}\right)$ & 0.173 & -0.209 & 0.043 & 0.270 & -0.285 \\
\hline Unskilled and semi-skilled & 0.300 & $-0.309 * *$ & $-0.305 * * *$ & 0.260 & -0.124 \\
\hline White-collar and skilled & 0.032 & $-0.638 *$ & -0.290 & 0.027 & $-0.617+$ \\
\hline Farm size 1 (lowest $5^{\text {th }}$ ) & 0.131 & 0.188 & -0.084 & 0.149 & 0.159 \\
\hline Farm size 2 & 0.198 & 0.033 & -0.128 & 0.209 & 0.103 \\
\hline Farm size 4 & 0.180 & $-0.293+$ & 0.000 & 0.178 & $-0.395 * *$ \\
\hline Farm size 5 (highest $\left.5^{\text {th }}\right)$ & 0.255 & $-0.539 * * *$ & $-0.277 * *$ & 0.197 & $-0.525 * * *$ \\
\hline Pop density 1 (lowest $\left.5^{\text {th }}\right)$ & 0.199 & $-0.350 *$ & $-0.260 *$ & 0.151 & $-0.311+$ \\
\hline Pop density 2 & 0.207 & -0.245 & -0.094 & 0.195 & -0.267 \\
\hline Pop density 4 & 0.184 & -0.237 & $-0.424 * * *$ & 0.210 & -0.124 \\
\hline Pop density 5 (highest $5^{\text {th }}$ ) & 0.158 & $-0.460 * * *$ & $-0.400 * * *$ & 0.164 & $-0.391 * *$ \\
\hline Enlisted in border states & 0.492 & -0.101 & $1.715 * * *$ & 0.597 & $-0.516 * * *$ \\
\hline Enlisted prior to Mar. 1863 & 0.006 & $4.203 * *$ & $4.401 * *$ & 0.009 & 1.151 \\
\hline Enlisted after June 1864 & 0.517 & -0.145 & $-0.402 * * *$ & 0.467 & 0.170 \\
\hline Higher initial rank & 0.054 & -0.158 & 0.003 & 0.060 & -0.179 \\
\hline Non-infantry duty & 0.245 & $-0.723 * * *$ & -0.148 & 0.239 & $-0.730 * * *$ \\
\hline & & $\begin{array}{l}-2 \operatorname{LogL}= \\
1589.478 \\
\text { Chi-square= } \\
122.054 \\
\text { P-value }= \\
0.000\end{array}$ & $\begin{array}{l}-2 \operatorname{LogL}= \\
2531.944 \\
\text { Chi-square = } \\
194.319 \\
\text { P-value }= \\
0.000\end{array}$ & & $\begin{array}{l}-2 \operatorname{LogL}= \\
1167.597 \\
\text { Chi-square } \\
=96.641 \\
\text { P-value }= \\
0.000\end{array}$ \\
\hline
\end{tabular}

Notes: The number of observations is 1887 for regressions (1) and (2), and 998 for regression (3). Dependent variables are dummy variables that equal 1 if a person died from a disease for regressions (1) and (3), if a person contracted a disease for regression (2), and zero otherwise. NI = not included. The omitted categories are (1) black skin color, (2) height $3^{\text {rd }}$ quintile, (3) field hands, (4) plantation size $3^{\text {rd }}$ quintile, (5) population density $3^{\text {rd }}$ quintile, (6) enlisted in the Confederate states, (7) enlisted between March 1863 and June 1864, (8) privates, and (9) infantrymen.

$* * *$ significance at $1 \%$ level, **significance at $5 \%$ level, *significance at $10 \%$ level, + significance at $15 \%$ level 
Even after black men were officially mustered in the army, they were discriminated against in various ways. Black recruits were not permitted to become commissioned officers, and were paid much less than white soldiers of the same rank. Furthermore, they were much more likely to be assigned to heavy manual duties while white solders were sent to fight in the battlegrounds. In June 1864, Congress passed an act equalizing the pay of black and white soldiers. At the same time, excessive fatigue duty for black troops was banned, too. To consider the effects of these major changes in the rules regarding the treatment of black men, the dates of enlistment were classified into three periods: (1) May 1863 and earlier, (2) June 1863 to June 1864, and (3) after June 1864.

Previous studies of white Union Army recruits have suggested that military rank and duty had very strong effects on the chances of dying while in service (Lee 1999, 2003). Lee (1999) has also shown that military positions were selectively assigned to the newly enlisted according to their socioeconomic backgrounds. Descriptive evidence confirms that the assignments of military positions in black regiments were also selective. Artisans, house servants, and other privileged bondsmen provided the bulk of the noncommissioned officers. Also, black soldiers who had been free led demands for commissioned office and monopolized those ranks after Union policy changed (Berlin, Reidy, and Rowland 1998, 35-36). To control for this potential indirect effect of socioeconomic characteristics on the probability of dying through the assignments of military positions, dummy variables on duty (which equals 1 if noninfantrymen and 0 otherwise) and rank (equals 1 if higher than private and 0 otherwise) were included.

The regression results are presented in Table $3 .^{10}$ The estimated parameters for the variables on skin color, occupation, plantation size, and population density generally confirm the patterns of mortality differentials described above. ${ }^{11}$ Brown-

\footnotetext{
${ }^{10}$ OLS and probit regressions were also performed using the same set of variables. The results are very similar those of logistic regressions.

${ }^{11}$ The predictive potential of each logistic model was examined in the following way; the regression concerning the probability of contracting a disease is presented here as an example. An event observation (a person who suffered from disease) was counted as a correctly predicted case if its predicted probability was equal to or higher than the sample mean of the dependent variable $(0.518$ in this case). Similarly, a non-event observation was regarded as a correctly predicted case if its predicted probability was lower than the sample mean. Where
} 
skinned men were significantly less likely to contract and die from diseases than darkskinned soldiers. But the favorable effect of light skin is no longer visible once other personal characteristics are held constant. Former white-collar and skilled workers were less likely to contract and to be killed by diseases than field hands, although the effect of elite occupations on the probability of contracting diseases misses statistical significance by a relatively small margin. Having resided in the top-quintile counties in the distribution of the plantation size strongly diminished the probabilities of contracting and dying from diseases and the conditional probability of being killed by diseases. Recruits from counties that belonged to the top category of population density were much less likely to succumb to and die from disease in the event of contraction.

Age had a U-shaped relationship with the probability of suffering a disease while in service. The estimated parameters for age and age squared suggest that the probability of contraction first decreased with age, reached the minimum around age 34, and increased with age thereafter. Since few men aged 34 and older entered the army, the effect of age on the probability of contracting diseases was practically negative. The effect of age on the conditional probability of dying from disease in case of contraction was not statistically significant.

It is surprising to find that the association between height and the probability of contracting disease was positive, not negative. The shortest 20 percent were significantly less likely to be killed by disease while in service. If height was included in the regressions as a continuous variable, it showed a strong positive relationship with the probabilities of contracting disease and dying from disease. Height was not systematically related to the conditional probability of dying from disease in case of contraction. One possible explanation for this unexpected outcome is that army recruits received the same ration regardless of their stature. If this was the case, a taller solder could have been relatively undernourished compared to a shorter man because a

this method was applied, about 60 percent of the event and non-event observations were correctly predicted by the model employed in this study. The relatively rare event nature of some regressions does not seem to significantly affect the predictive power. In the case of the regression for the probability of dying from immunity diseases, reported in Table 4, the dependent mean was only 0.042 , the lowest of all regressions. However, the proportions of the event and non-event observations that were correctly predicted by the model were, respectively, 73.3 percent and 53.5 percent. 
greater amount of energy was required to maintain a bigger body.

In contrast to the patterns of mortality differentials reported in Table 3, men who enlisted in the border states were no different from enlistees from Confederate states. The significantly lower conditional probability of dying from disease among the soldiers from the border states is completely offset by their much higher risks of contracting diseases. Men who enlisted later were much less likely to be killed by disease than earlier enlistees. The relationship between the year of enlistment and the wartime mortality from disease is largely explained by the different average length of military service according to the timing of enlistment. The average number of disease cases per person-year (a measure of the probability of contracting a disease after being standardized for the length of service) was actually higher for the late enlistees. Furthermore, the case fatality rate was no different between men who enlisted in different years. This result implies either or both of the following: first, the smaller pay or excessively heavy duty of black recruits did not seriously impair their health; and second, the act of June 1864 to equalize the pay of black and white soldiers and to prohibit the excess fatigue duty for blacks was not effectively enforced.

As in the case of whites, serving on non-infantry duty significantly diminished the probabilities of suffering and dying from disease. On the other hand, noncommissioned officers had no advantages over privates in black regiments whereas white men at higher ranks enjoyed much lower rates of death and contraction of disease than privates. Unlike white non-commissioned officers who were paid more than privates, black servicemen received the same pay regardless of their rank. This difference in pay scheme could be in part responsible for the racial difference in the relationship between of military rank and wartime mortality.

\section{Nutrition, Immunity, and Wartime Mortality}

Previous studies of the experiences of white Union Army soldiers have suggested two important mechanisms by which socioeconomic background prior to enlistment affected wartime health (Lee 1997, 2003, Smith 2003). First, a recruit from a healthier environment had been less exposed to disease and thus had poorer immunity against disease than a man from an unhealthy place. There is a great deal of evidence demonstrating the fragility of an isolated population once they come in 
contact with different disease pool (McNeill 1976, Curtin 1989, Pritchett and Tunali 1995, Fetter and Kessler 1996, Sköld 1997). It provides a plausible explanation for why farmers and rural residents were more likely to contract diseases and be killed by them than were non-farmers and city dwellers, respectively. Despite the negative consequences for net nutritional status, survivors of unhealthy environments developed better immunity to some of the infectious diseases that were rampant in army life. Second, a person who had been better nourished had advantages over a man with poorer nutritional status in terms of avoiding or resisting some nutritionally-sensitive diseases. This is a possible reason for the negative relationship between household wealth and the probability of contracting some types of diseases among white Union Army recruits (Lee 1997, 2003).

The two potential pathways by which pre-service socioeconomic characteristics affected wartime mortality could be mixed in the regression results reported above. Given that black soldiers who had been engaged in elite occupations were presumably better nourished than field hands and that some of them probably resided in town, their lower rates of disease contraction and mortality compared to field hands may have resulted from both greater immunity to diseases and superior nutritional status. Servicemen from more densely populated counties should have had more chances to develop immunity against diseases than men from more isolated areas. However, this advantage of urban dwellers could have been offset by their poorer initial nutritional status.

The relative importance of each of the two links between socioeconomic background and wartime health can be examined by looking at cause-specific morbidity and mortality. According to epidemiological studies, the strength of immunity to disease from prior contraction differs from one disease to another. For some diseases, such as measles, smallpox, and typhoid, an attack would confer immunity and thus reduce the probability of contracting or dying from those diseases in the future (such diseases will be called immunity diseases below). For other diseases, such as malaria, diarrhea, dysentery, and pneumonia, a prior contraction has little influence on susceptibility or resistance to a later contraction (this type will be called 
non-immunity diseases). ${ }^{12}$ Most diseases are sensitive to nutritional status to some extent, but there are some diseases for which the effect of nutritional status is particularly strong, including diarrhea, tuberculosis, most respiratory infections, pertussis, cholera, leprosy, and herpes (Journal of Interdisciplinary History 1983, 506). For non-immunity diseases, the effect of prior nutritional status should be stronger than the effect of immunity. Logistic regressions were performed to examine the effects of socioeconomic backgrounds and military experiences on the probabilities of contracting and dying from these two types of diseases, employing the same set of variables included in the regressions for all types of diseases. Tables 4 and 5 present the results.

The advantages of light-skinned men in resisting diseases while in service, though marginally insignificant at a conventional significance level, were stronger for non-immunity diseases than for immunity diseases. Since occupational differences between skin colors are taken into account, this indicates that light-skinned slaves were perhaps better nourished and healthier than dark-skinned slaves even within the category of similar occupation. On the other hand, brown-skinned men were less likely to contract both types of diseases. It is uncertain what granted them this stronger immunity against diseases.

Having non-field occupations prior to enlistment significantly diminished the risk of contracting non-immunity diseases while in service. The estimated parameters suggest that, compared to field hands, the probability of suffering this type of disease was 39 percent lower for skilled workers and 23 percent lower for men who had other non-field occupations, although the effect of holding elite occupations misses statistical significance by a small margin. In sharp contrast, variables on occupation had no significant effect on immunity diseases. This suggests that the advantages of men working in elite or non-field occupations over field hands perhaps resulted from their superior nutritional status or general health conditions at the time of enlistment rather than the influence of differential immunity status. This pattern is clearly different from white recruits for whom the lower wartime mortality of non-farmers compared to

${ }^{12}$ For the epidemiological characteristics of these and other diseases, see May (1958), Steiner (1968, 12-26), Kunitz (1983, 351-53), and Kiple (2003). For more detailed documentation of the history of specific disease, see Fetter and Kessler (1996) for measles, Zurbrigg (1997) for malaria, and Sköld (1997) for smallpox. 
farmers largely reflected their better immunity against diseases (Lee 2003).

Table 4

Results of Logistic Regressions: Correlates of Probability of Dying from Immunity Disease ( $\left.\partial \mathrm{P} / \partial \mathrm{x}_{\mathrm{i}}\right)$

\begin{tabular}{|c|c|c|c|}
\hline \multirow[b]{2}{*}{ Independent Variables } & \multicolumn{2}{|c|}{ All Recruits } & \multirow{2}{*}{$\begin{array}{c}\text { Recruits Who } \\
\text { Contracted Disease } \\
(3) \\
\text { Dying from Disease } \\
(\text { mean }=0.304)\end{array}$} \\
\hline & $\begin{array}{l}(1) \\
\text { Dying from Disease } \\
(\text { mean }=0.047)\end{array}$ & $\begin{array}{c}(2) \\
\text { Contracting Disease } \\
(\text { mean }=0.091)\end{array}$ & \\
\hline Age & $-0.159 * * *$ & $-0.159 * * *$ & -0.046 \\
\hline $\mathrm{Age}^{2} \times 10^{-1}$ & $0.026 * * *$ & $0.023 * * *$ & 0.011 \\
\hline Skin color brown & $-0.747 *$ & -0.418 & $-0.788+$ \\
\hline Skin color light & -0.340 & 0.066 & -0.708 \\
\hline Height 1 (shortest $5^{\text {th }}$ ) & -0.180 & -0.228 & -0.191 \\
\hline Height 2 & 0.167 & -0.021 & 0.167 \\
\hline Height 4 & 0.198 & 0.143 & -0.296 \\
\hline Height 5 (tallest $\left.5^{\text {th }}\right)$ & 0.388 & 0.160 & 0.064 \\
\hline Unskilled and semi-skilled & 0.221 & -0.032 & 0.877 \\
\hline White-collar and skilled & $<-999.999$ & 0.080 & $<-999.999$ \\
\hline Farm size 1 (lowest $\left.5^{\text {th }}\right)$ & $1.234 * *$ & 0.175 & $4.370 * *$ \\
\hline Farm size 2 & -0.045 & -0.135 & 0.085 \\
\hline Farm size 4 & -0.249 & -0.250 & 0.291 \\
\hline Farm size 5 (highest $5^{\text {th }}$ ) & $-0.537 * *$ & $-0.586 * * *$ & 0.218 \\
\hline Pop density 1 (lowest $\left.5^{\text {th }}\right)$ & -0.223 & -0.181 & 0.042 \\
\hline Pop density 2 & -0.043 & 0.166 & -0.015 \\
\hline Pop density 4 & 0.569 & $-0.349+$ & $6.251 * *$ \\
\hline Pop density 5 (highest $5^{\text {th }}$ ) & $-0.746 * * *$ & $-0.619 * * *$ & -0.598 \\
\hline Enlisted in border states & $-0.664 * * *$ & -0.223 & $-0.738 * * *$ \\
\hline Enlisted prior to Mar. 1863 & $<-999.999$ & $<-999.999$ & NI \\
\hline Enlisted after June 1864 & $-0.348 *$ & -0.214 & -0.379 \\
\hline Higher initial rank & -0.107 & 0.133 & -0.311 \\
\hline Non-infantry duty & $-0.728 * * *$ & $-0.314^{*}$ & $-0.802 * * *$ \\
\hline & $\begin{array}{l}-2 \operatorname{LogL}=693.726 \\
\text { Chi-square }=74.036 \\
\text { P-value }=0.000\end{array}$ & $\begin{array}{l}-2 \log \mathrm{L}=1113.102 \\
\text { Chi-square }=58.261 \\
\mathrm{P} \text {-value }=0.000\end{array}$ & $\begin{array}{l}-2 \log \mathrm{L}=229.908 \\
\text { Chi-square }=48.000 \\
\mathrm{P} \text {-value }=0.000\end{array}$ \\
\hline
\end{tabular}

Notes: The number of observations is 1887 for regressions (1) and (2), and 172 for regression (3). Dependent variables are dummy variables that equal 1 if a person died from an immunity disease for regressions (1) and (3), if a person contracted a disease for regression (2), and zero otherwise. NI = not included. The omitted categories are (1) black skin color, (2) height $3^{\text {rd }}$ quintile, (3) field hands, (4) plantation size $3^{\text {rd }}$ quintile, (5) population density $3^{\text {rd }}$ quintile, (6) enlisted in the Confederate states, (7) enlisted between March 1863 and June 1864, (8) privates, and (9) infantrymen.

$* * *$ significance at $1 \%$ level, $* *$ significance at $5 \%$ level, *significance at $10 \%$ level, + significance at $15 \%$ level 
Table 5

Results of Logistic Regressions: Correlates of Probability of Dying from Non-Immunity Disease $\left(\partial P / \partial x_{\mathrm{i}}\right)$

\begin{tabular}{|c|c|c|c|}
\hline \multirow[b]{2}{*}{ Independent Variables } & \multicolumn{2}{|c|}{ All Recruits } & \multirow{2}{*}{$\begin{array}{c}\text { Recruits Who } \\
\text { Contracted Disease } \\
(3) \\
\begin{array}{c}\text { Dying from Disease } \\
(\text { mean }=0.218)\end{array}\end{array}$} \\
\hline & $\begin{array}{l}(1) \\
\text { Dying from Disease } \\
(\text { mean }=0.063)\end{array}$ & $\begin{array}{c}(2) \\
\text { Contracting Disease } \\
(\text { mean }=0.518)\end{array}$ & \\
\hline Age & 0.075 & -0.003 & $0.112+$ \\
\hline $\operatorname{Age}^{2} \times 10^{-1}$ & -0.008 & 0.000 & -0.012 \\
\hline Skin color brown & -0.104 & $-0.642 * * *$ & 1.411 \\
\hline Skin color light & $-0.784+$ & -0.273 & $-0.784+$ \\
\hline Height 1 (shortest $\left.5^{\text {th }}\right)$ & -0.314 & -0.056 & -0.371 \\
\hline Height 2 & $-0.427 *$ & -0.121 & $-0.516 *$ \\
\hline Height 4 & -0.333 & $0.309+$ & $-0.525 * *$ \\
\hline Height 5 (tallest $\left.5^{\text {th }}\right)$ & -0.265 & $0.350+$ & $-0.492 *$ \\
\hline Unskilled and semi-skilled & $-0.345 *$ & $-0.234 * *$ & -0.200 \\
\hline White-collar and skilled & -0.711 & -0.391 & -0.566 \\
\hline Farm size $1\left(\right.$ lowest $\left.5^{\text {th }}\right)$ & 0.292 & -0.116 & 0.611 \\
\hline Farm size 2 & 0.089 & -0.086 & 0.194 \\
\hline Farm size 4 & $-0.447 *$ & -0.076 & $-0.541 *$ \\
\hline Farm size 5 (highest $\left.5^{\text {th }}\right)$ & $-0.460 *$ & 0.008 & $-0.550 *$ \\
\hline Pop density 1 (lowest $5^{\text {th }}$ ) & $-0.524 * *$ & $-0.323 * *$ & -0.407 \\
\hline Pop density 2 & $-0.458 *$ & -0.188 & -0.398 \\
\hline Pop density 4 & -0.132 & -0.199 & 0.037 \\
\hline Pop density 5 (highest $5^{\text {th }}$ ) & $-0.438 *$ & $0.256 *$ & $-0.417+$ \\
\hline Enlisted in border states & 0.160 & $0.867 * * *$ & $-0.394+$ \\
\hline Enlisted prior to Mar. 1863 & $3.046+$ & 1.043 & 2.108 \\
\hline Enlisted after June 1864 & 0.200 & $-0.321 * * *$ & $0.749 * *$ \\
\hline Higher initial rank & -0.034 & -0.037 & 0.085 \\
\hline Non-infantry duty & $-0.778 * * *$ & $-0.213 *$ & $-0.245 * * *$ \\
\hline & $\begin{array}{l}-2 \log \mathrm{L}=864.323 \\
\text { Chi-square }=73.684 \\
\text { P-value }=0.000\end{array}$ & $\begin{array}{l}-2 \log L=2203.726 \\
\text { Chi-square }=101.698 \\
\text { P-value }=0.000\end{array}$ & $\begin{array}{l}-2 \log \mathrm{L}=557.493 \\
\text { Chi-square }=62.541 \\
\text { P-value }=0.000\end{array}$ \\
\hline
\end{tabular}

Notes: The number of observations is 1887 for regressions (1) and (2), and 545 for regression (3). Dependent variables are dummy variables that equal 1 if a person died from a non-immunity disease for regressions (1) and (3), if a person contracted a non-immunity disease for regression (2), and zero otherwise. NI = not included. The omitted categories are (1) black skin color, (2) height $3^{\text {rd }}$ quintile, (3) field hands, (4) plantation size $3^{\text {rd }}$ quintile, (5) population density $3^{\text {rd }}$ quintile, (6) enlisted in the Confederate states, (7) enlisted between March 1863 and June 1864, (8) privates, and (9) infantrymen. $* * *$ significance at $1 \%$ level, $* *$ significance at $5 \%$ level, *significance at $10 \%$ level, + significance at $15 \%$ level

Black soldiers from counties in which the average plantation size was large were significantly less likely to die from both types of diseases, but the mechanism by which plantation size affected wartime mortality differed by the type of disease. In case of immunity diseases, the advantages of living on large plantations largely came from their lower rate of disease contraction. On the other hand, the major reason for 
these recruits' lower mortality from non-immunity diseases was the lower probability of dying from non-immunity diseases in case of contraction. Living with a large number of slaves in the same plantation should have provided more chances to contact diseases and thus develop immunity against them. This result also suggests that slaves on large plantations were probably better nourished on average than slaves on smaller holdings. Alternatively, a larger fraction of slaves on smaller plantations were inadequately nourished to the point that their later health would be impaired by poor nutritional status. The latter explanation is more consistent with the finding of Crawford (1992) that the vast majority of slaves on the large plantations ate just an adequate diet, while those on smaller holdings were more likely to experience either inadequate or significantly better-than-adequate diets.

Residing in urban counties prior to enlistment strongly lowered the probabilities of contracting and dying from immunity diseases. Recruits from a county that belonged to the top quintile of the population density were 62 percent less likely to suffer immunity diseases and 75 percent less likely to be killed by those illnesses. If non-immunity diseases are considered, on the other hand, the relationship between the county population density and wartime mortality is much less straightforward. Indeed, recruits from the top-quintile counties in terms of population density were more likely to succumb to non-immunity diseases.

The effect of age on wartime morbidity and mortality differs by the type of disease. For immunity diseases, the probability of contracting a disease and the probability of dying from a disease decreased with age through the early thirties. Since most recruits were younger than thirty at the time of enlistment, the relationship between age and wartime mortality is practically negative. Perhaps aged persons had developed stronger immunity to diseases because they had been more exposed to diseases than younger men before they entered the army. For non-immunity diseases, age had no significant effect on the odds of contracting diseases and the conditional probability of dying from the disease contracted.

The regression results for all types of diseases (presented in Table 3) show that the recruits who enlisted in the border states were more likely to contract diseases but less likely to die from diseases they contracted than those who joined the Union Army in the Confederate states. The regression results for non-immunity diseases (Table 5) 
are similar to the result for all diseases. In contrast, if only immunity diseases are concerned, enlistees from the border states were significantly less likely to die from diseases largely due to their lower case fatality rates.

The time pattern of wartime mortality provides another clue by which the influences of prior immunity and nutritional status can be examined. It is documented in the medical histories of the Civil War that the earlier seasoning period in the army was most critical for the survival of recruits. During this period, enlistees with limited immunity were exposed to a pool of various infectious diseases in the army (Steiner 1968). If the differences in wartime mortality between men from the countryside and urban areas were mainly caused by differences in immunity status, most of the differences should have occurred in the early stages of military service when the recruits were not seasoned to the severe disease environment of the army camps. The time pattern of wartime death also offers a hint as to how long the advantages of having superior nutritional status or generally good health at the time of enlistment, as indicated by the recruits' occupation, persisted with the duration of military service.

Table 6 reports the calculated hazard rate of dying from a particular type of disease for each 180-day interval from the time of enlistment. The hazard rate for the 181-360 day period, for example, shows what proportion of the recruits remaining alive in service at the beginning of $181^{\text {st }}$ day died from any illness or some specific type of disease within the following 180 days. If a soldier died from any cause or was discharged alive between enlistment and $180^{\text {th }}$ day, he is removed from the population at risk when the hazard rate of the next time interval $\left(360^{\text {th }}\right.$ to $540^{\text {th }}$ day) is calculated..$^{13}$ The result for the dwellers in rural and urban areas is graphically presented in Figure 1.

The time patterns of wartime mortality are generally consistent with the immunity hypothesis. Hazard rates of dying from disease were higher during the first six months than in subsequent periods, confirming the remarks on the seasoning period given in medical histories of the Civil War. In particular, the mortality for the enlistees

\footnotetext{
${ }^{13}$ To calculate the population at risk at the beginning of each time interval, the number of recruits who were discharged from service should be computed. Unfortunately, the exact timing of discharge can only be determined for about 26 percent of the sample because of missing information on the date of discharge. I estimated the number of the discharged for each time interval based on the assumption that, for each type of man (e.g. field hands, non-farm workers, urban residents, and rural residents), the time patterns of discharge for the entire sample and for the recruits for whom the date of the discharge is known are the same.
} 
from rural areas was extremely high within the first six months and then declined dramatically in subsequent periods. In contrast, the mortality of urban residents was relatively low at the early stage of service and exhibits no clear time pattern. As a consequence, a disproportionately large fraction of the differences between rural and urban residents was made in the first six months in the army.

Table 6

Hazard Rates of Dying from Disease: Number of Deaths per 1000 Men within 180-Day Intervals

\begin{tabular}{|c|c|c|c|c|c|c|}
\hline \multicolumn{7}{|c|}{ A. Any illnesses } \\
\hline Days & Field hands & Non-field & Rural & Urban & Small farm & Large farm \\
\hline $0-180$ & 74.7 & 64.1 & 71.5 & 35.5 & 71.6 & 48.1 \\
\hline $181-360$ & 53.4 & 31.3 & 34.8 & 65.4 & 46.2 & 21.1 \\
\hline $361-540$ & 49.0 & 30.8 & 44.5 & 40.8 & 52.8 & 19.2 \\
\hline $541-720$ & 32.9 & 33.8 & 37.8 & 25.4 & 37.7 & 31.0 \\
\hline \multicolumn{7}{|c|}{ B. Immunity diseases } \\
\hline Days & Field hands & Non-field & Rural & Urban & Small farm & Large farm \\
\hline $0-180$ & 21.7 & 12.2 & 19.7 & 5.9 & 20.7 & 7.7 \\
\hline $181-360$ & 12.9 & 13.1 & 11.6 & 9.8 & 11.9 & 9.4 \\
\hline $361-540$ & 10.9 & 6.0 & 18.0 & 0.0 & 16.8 & 9.6 \\
\hline $541-720$ & 0.9 & 13.8 & 11.6 & 0.0 & 8.6 & 13.3 \\
\hline \multicolumn{7}{|c|}{ C. Non-immunity diseases } \\
\hline Days & Field hands & Non-field & Rural & Urban & Small farm & Large farm \\
\hline $0-180$ & 29.2 & 17.7 & 32.1 & 17.8 & 33.3 & 19.2 \\
\hline $181-360$ & 26.2 & 11.6 & 16.4 & 29.4 & 22.4 & 7.0 \\
\hline $361-540$ & 24.5 & 13.9 & 19.1 & 30.6 & 27.6 & 3.2 \\
\hline $541-720$ & 19.2 & 7.7 & 14.5 & 16.9 & 15.4 & 13.3 \\
\hline
\end{tabular}

Notes: The hazard rates for rural and urban residents and small and large farms are calculated based on the sample of ex-slaves for who the information on county of residence is given. The number of recruits who died from a particular type of disease within each 180-day interval was divided by the number of recruits who remained in service at the beginning of the time interval and then was multiplied by 1,000 . If a recruit died from any other cause while in service or discharged alive, he was removed from the pool of population at risk. Since the discharge dates are reported for only a fraction of the recruits, the number of persons who discharged alive within each interval is estimated based on the experiences of those who have that information. For the classification of disease see text. 
Figure 1 Hazard Rates of Dying from Disease by the Type of Disease

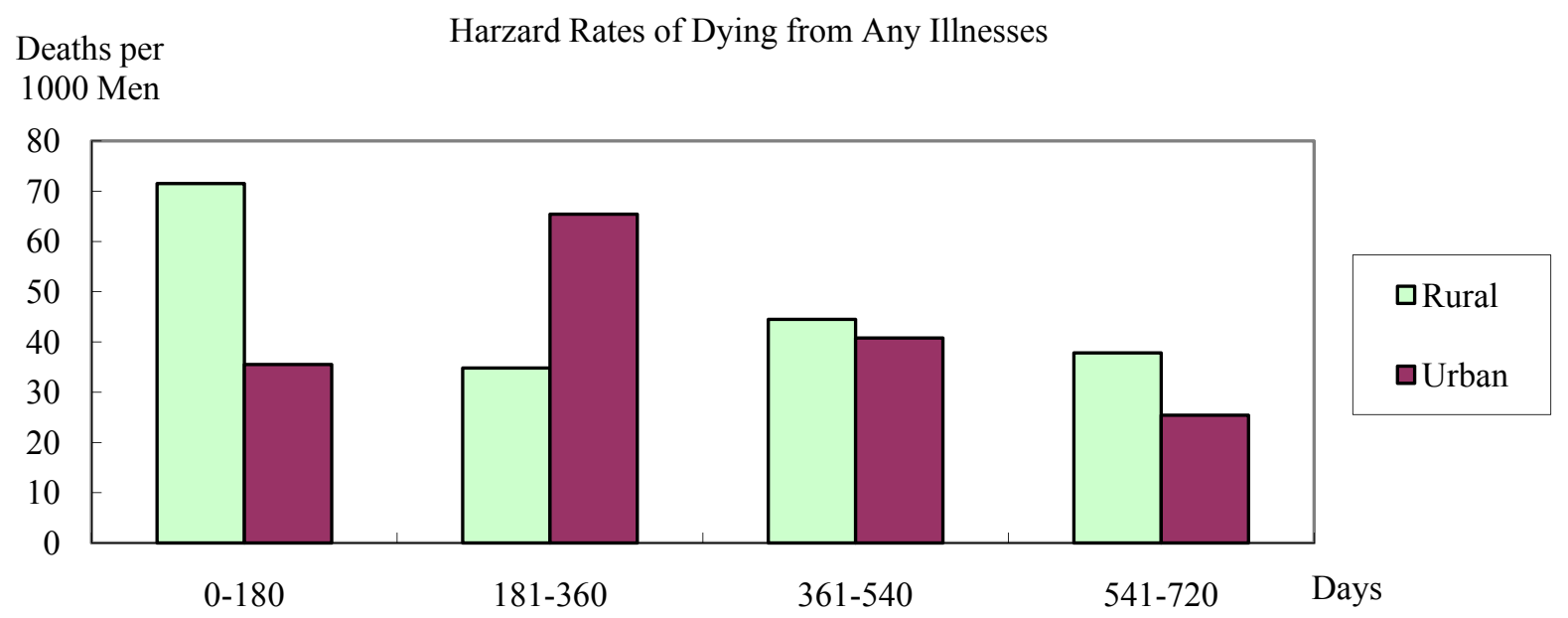
Deaths per Harzard Rates of Dying from Immunity Diseases
1000 Men
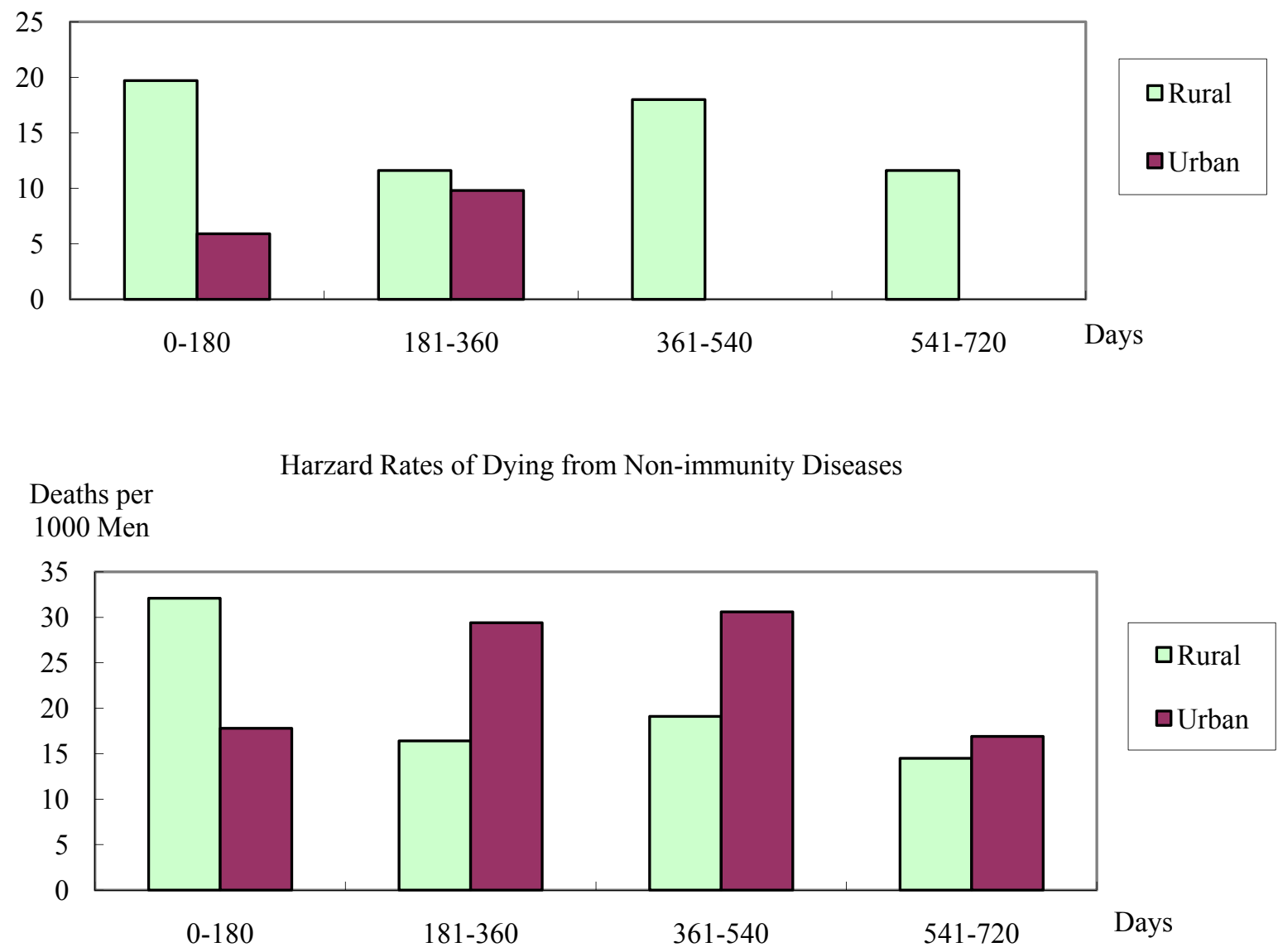
For recruits who probably lacked immunity against diseases (field hands, rural residents, and men from small farms), the mortality from immunity diseases was particularly high during the first six months and dropped sharply thereafter, which is consistent with the prediction of the immunity hypothesis. In contrast, the hazard rate of dying from immunity diseases among men who presumably had better immunity status (non-field occupations, urban residents, and ex-slaves from large plantations) do not exhibit a clear time pattern.

However, if non-immunity diseases are examined, the disease-caused mortality among rural residents was much higher in the first six months than in the following periods. Also, the differences in mortality from non-immunity diseases between urban and rural residents and between men from small and large plantations were particularly high in the first half year. This result suggests that immunity may not be the only explanation for the particularly high mortality from disease among the army recruits. Another possible explanation is that, as recruits continued to be exposed to disease in the army camp, they gained knowledge that helped them avoid contraction. People who had lived in unhealthy circumstances, such as urban areas, were more aware of ways to avoid contracting disease than those with little experience with disease. According to a qualitative record about white Union Army soldiers, for example, Germans ate fewer sweets, cooked their food more carefully, and more actively pursued cleanliness (Hess 1981, 66-67). A number of contemporary accounts suggest that rural residents and farmers were particularly unhygienic and ignorant of child health (Preston and Haines 1991, 38-39). Alternatively, it could be explained by population selections caused by differential mortality; that is, first, individuals who survived an unhealthy environment were on average more robust (which explains why men from urban areas experienced lower mortality than those from rural areas), and, second, less-healthy recruits tended to die early, leaving only healthier men in the later stages of military service (which explains why even the hazard of death caused by nonimmunity diseases declined with the duration of service).

It is not entirely clear why non-farmers were less likely to be killed by disease than field hands while in service. The skilled and other non-field workers were perhaps better nourished because of their more elite occupations. It may have been the case that non-farmers' overall health, rather than nutritional status, was better than that of field 
hands. The effect of differential nutritional status prior to enlistment, if any, should have been stronger in the earlier period in military service. Initially better-nourished recruits would eventually lose their advantage as they continued to face a poorer diet and the fight against disease in the army. Therefore, if different nutrition is the major story, the difference in mortality from non-immunity diseases between non-farmers and field hands should have been greater in the earlier period in service.

The results in Table 6 only weakly support this "nutrition hypothesis." The mortality differential was the widest in the first six months and diminished over time. But the advantages of non-farmers persisted throughout their military service, suggesting that different nutritional status may not have been the only factor. The results also suggest that the advantages of non-farmers over field hands could be in part attributable to their stronger immunity. Mortality from immunity diseases within the first six months was nearly twice as high for field hands as for men engaged in non-field jobs. The regression results presented in Table 4 (showing no significant effect of occupation on the probability of dying from immunity diseases) fail to capture it because the mortality from immunity diseases in later periods was higher for nonfield slaves than it was for field hands.

In general, the patterns of wartime mortality differentials of black Union Army soldiers are not much different from the features of socioeconomic differences in the disease mortality of white recruits suggested in previous studies. Among white soldiers as well, former farmers and men from rural areas were more vulnerable to disease in army camps than non-farmers and city-dwellers, respectively (Lee 1997, 2003). A notable difference is that height is positively related to the probability of contracting diseases for black enlistees, whereas white recruits' health while in service was not significantly affected by height. Given that the climate, disease environment, and extent of urbanization were considerably different between the North and the South, and that the occupational hierarchy and living conditions differed between the free white and slave populations, these similarities in the socioeconomic disparities in wartime health and mortality are remarkable. The evidence given here further confirms the importance of nutritional and immunity status as major determinants of the health of the nineteenth-century population at large. 


\section{Conclusions and Implications}

This paper has investigated the patterns of socioeconomic differences in wartime morbidity and mortality of black Union Army soldiers. Lighter-skinned men were less likely to contract and die from diseases. Former slaves engaged in non-field occupations were less likely to contract and to be killed by diseases than were field hands. Ex-slaves from large plantations were at much lower risk of contracting and dying from diseases. Residing in urban areas prior to enlistment strongly diminished the chances of suffering and dying from diseases. The relationship between age and the probability of contracting diseases was practically negative.

The study has found that the association between height and the probability of contracting disease was positive, not negative. A possible explanation for this unexpected outcome is that army recruits received the same amount of food regardless of their stature and therefore a taller solder was relatively undernourished compared to a shorter man. As in the case of white recruits, serving on non-infantry duty significantly diminished the probabilities of suffering and dying from disease. On the other hand, non-commissioned officers had no advantages over privates in black regiments, whereas white men at higher ranks enjoyed much lower rates of death and contraction of disease than privates.

Patterns of disease-specific mortality and timing of death suggest that the differences in the development of immunity against diseases and nutritional status prior to enlistment were responsible for the observed mortality differentials. The advantages of light-skinned soldiers over dark-skinned men and of men who held non-field occupations over field hands perhaps resulted from their superior nutritional status prior to enlistment. The effect of plantation size on wartime mortality appears to reflect the advantages of men from large plantations in terms of both better-developed immunity and superior nutritional status. Residing in urban counties should have provided more chances to contact diseases and develop immunity against them.

The results of this paper suggest that there were substantial disparities in the health of the slave population on the eve of the Civil War. The standard of living and the quality of environment probably differed by skin color, occupation, plantation size, and population aggregation. Light-skinned slaves and those assigned to elite or other non-field occupations appear to have enjoyed better diets, lower work burdens, and 
healthier environments compared to dark-skinned slaves and field hands, respectively. Slaves on a large-scale plantation were perhaps more exposed to diseases because of higher chances of contact with other infected people. On the other hand, it appears that the standards of living were higher for slaves in larger plantations than those on smaller farms. Slaves living on a plantation located in a more densely populated area were perhaps less healthy than those residing on an isolated farm.

This study also indicates that the more favorable climate for the development of infectious diseases was perhaps a major factor that shaped the lives of the people in the antebellum U.S. South. Living on large plantations was probably less desirable for slaves because of higher chances of contracting diseases in spite of more generous provisions of food on those farms. For masters, greater concerns about poor health and higher morality of slaves could have offset some of the potential economic advantages of operating large-scale plantations. Geographic moves, both before and after the Emancipation, should have adversely affected the health of the black migrants by making them encounter different disease environments they had not been seasoned to.

\section{References}

Berlin, Ira, Joseph P. Reidy, and Leslie S. Rowland, Eds. 1982. The Black Military Experience. Series II in Freedom: A Documentary History of Emancipation, 18611867. Cambridge: Cambridge University Press.

Berlin, Ira, Joseph P. Reidy, and Leslie S. Rowland, Eds. 1998. Freedom's Soldiers: The Black Military Experiences in the Civil War. Cambridge-New York: Cambridge University Press.

Crawford, Stephen C. 1992. "A Note on the Relationship between Plantation Size and Diet Adequacy," In Fogel, Robert W., Ralph A. Galantine, and Richard L. Manning eds., Without Consent or Contract: Evidence and Methods, New York: W. W. Norton \& Company.

Curtin, P. D. 1989. Death by Migration, Cambridge: Cambridge University Press.

Fetter, B., and Kessler, S. 1996. Scars from a Childhood Disease: Measles in the Concentration Camps during the Boer War, Social Science History 20, 593-611.

Fogel, Robert W. 1989. Without Consent or Contract: The Rise and Fall of American Slavery, New York: W. W. Norton \& Company. 
. 1993. "New Sources and New Techniques for the Study of Secular Trends in Nutritional Status, Health, and Mortality, and the Process of Aging," Historical Methods 26, 5-44.

1994. "Economic Growth, Population Theory, and Physiology: The Bearing of Long-Term Processes on the Making of Economic Policy," American Economic Review 84(3), 369-395.

. 2000a. Public Use Tape on the Aging of the Veterans of the Union Army Data User's Manual: Military, Pension, and Medical Records 1820-1940, Version M-5, Center for Population Economics, University of Chicago and Department of Economics, Brigham Young University.

. 2000b. Public Use Tape on the Aging of the Veterans of the Union Army Data User's Manual: U.S. Federal Census Records 1850, 1860, 1900, 1910, Version C-3, Center for Population Economics, University of Chicago and Department of Economics, Brigham Young University.

. 2001. Public Use Tape on the Aging of the Veterans of the Union Army Data User's Manual: Surgeon's Certificates 1862-1940, Version S-1 Standardized, Center for Population Economics, University of Chicago and Department of Economics, Brigham Young University.

Fogel, Robert W., Ralph A. Galantine, and Richard L. Manning. 1992. Without Consent or Contract: Evidence and Methods, New York: W. W. Norton \& Company.

Genovese, Eugene D. 1976. Roll, Jordan, Roll: The World the Slaves Made, New York: Vintage.

Haines, Michael R. 2000. The Population of the United States, 1790-1920, In Stanley L. Engerman and Robert E. Gallman, eds., The Cambridge Economic History of the United States, Cambridge University Press.

Hargrove, Hondon B. 1988. Black Union Soldiers in the Civil War. Jefferson, NC and London: McFarland and Company, Inc.

Hess, E. J. 1981. The 12th Missouri Infantry: A Socio-Military Profile of a Union Regiment. Missouri Historical Review 76, 53-77.

Journal of Interdisciplinary History. 1983. "The Relation of Nutrition, Diseases, and Social Conditions: A Graphical Presentation," Journal of Interdisciplinary History 14, 503-506.

Kiple, Kenneth F. 2003. The Cambridge Historical Dictionary of Disease, Cambridge University Press. 
Kunitz, S. J. 1983. Speculations on the European Mortality Decline. Economic History Review 36, 349- 64.

Lee, Chulhee. 1997. "Socioeconomic Background, Disease, and Mortality among Union Army Recruits: Implications for Economic and Demographic History," Explorations in Economic History 34, 27-55.

. 1999. "Selective Assignment of Military Positions in the Union Army: Implications for the Impact of the Civil War," Social Science History 23, 67-97.

2003. "Prior Exposure to Disease, and Later Health and Mortality: Evidence from Civil War Medical Records," In D. Costa, ed., Health and Labor Force Participation over the Life Cycle. Chicago: University of Chicago Press, 51-88.

Margo, Robert. 1992. "Civilian Occupations of Ex-Slaves in the Union Army, 18621865," In Robert W. Fogel and Stanley L. Engerman, eds., Without Consent or Contract: Conditions of Slave Life and the Transition to Freedom Technical Papers, Volume 1, New York: Norton.

Margo, Robert A., and Richard H. Steckel. 1992. "The Nutrition and Health of Slaves and Antebellum Southern Whites," In Robert W. Fogel and Stanley L. Engerman, eds., Without Consent or Contract: Conditions of Slave Life and the Transition to Freedom Technical Papers, Volume 2, New York: Norton.

May, J. M. 1958. The Ecology of Human Disease. New York: MD Publications.

McNeil, W. H. 1976. Plagues and People, Garden City, N.Y.: Doubleday.

Preston, S. H., and Haines, M. R. 1991. Fatal Years: Child Mortality in Late Nineteenth Century America. Princeton NJ: Princeton University Press.

Pritchett, J. B., and İ. Tunal1. 1995. "Strangers' Disease: Determinants of Yellow Fever Mortality during the New Orleans Epidemic of 1853" Explorations in Economic History 32, 517-539.

Smith, Daniel S. 2003. "Seasoning, Disease Environment, and Conditions of Exposure: New York Union Army Regiments and Soldiers," In D. Costa, ed., Health and Labor Force Participation over the Life Cycle. Chicago: University of Chicago Press, 89-112.

Steckel, Richard. 1986. "A Peculiar Population: The Nutrition, Health, and Mortality of American Slaves from Childhood to Maturity," Journal of Economic History 46, 721-741.

Steiner, P. E. 1968. Disease in the Civil War: Natural Biological Warfare in 18611865. Springfield, Ill: Charles C. Thomas Publisher.

Sköld, P. 1997. Escape from Catastrophe. Social Science History 21, 1-25. 
U.S. Surgeon General's Office. 1870. Medical and Surgical History of the War of the Rebellion. Washington, DC: Government Printing Office.

Waaler, H. 1984. "Height, Weight, and Mortality: The Norweigian Experience," Acta Medica Scandinavia 679, 1-56.

Wimmer, L. 2003. "Reflections on the 'Early Indicator's Project': A Partial History," In D. Costa, ed., Health and Labor Force Participation over the Life Cycle. Chicago: University of Chicago Press, pp. 1-10.

Zubrigg, S. 1997. Did Starvation Protect from Malaria? Social Science History 21, 2758. 